\title{
Specific and Time-Dependent Effects of Glucocorticoid Receptor Agonist RU28362 on Stress-Induced Pro-Opiomelanocortin hnRNA, c-fos mRNA and zif268 mRNA in the Pituitary
}

\author{
A. B. Ginsberg, M. G. Frank, A. B. Francis, B. A. Rubin, K. A. O'Connor and R. L. Spencer \\ Department of Psychology and Center for Neurosciences, University of Colorado at Boulder, Boulder, Colorado, USA.
}

Key words: glucocorticoid, stress, POMC, c-fos, zif268, rat.

\begin{abstract}
This study examined the effects of the glucocorticoid receptor (GR) agonist RU28362 on stress-induced gene expression in the pituitary of rats to investigate mechanisms of glucocorticoid negative feedback in vivo. In an initial experiment, acute restraint stress produced rapid (within $15 \mathrm{~min}$ ) induction of c-fos mRNA, zif268 mRNA and pro-opiomelanocortin (POMC) hnRNA within the anterior and intermediate/posterior pituitary as determined by quantitative real-time polymerase chain reaction. Treatment with RU28362 (150 $\mu \mathrm{g} / \mathrm{kg}$, i.p.) 60 min before restraint inhibited adrenocorticotrophic hormone (ACTH) and corticosterone secretion and selectively suppressed the stress-induced increase in POMC hnRNA in the anterior pituitary gland. The failure of RU28362 to surpress the stress-induced rise in c-fos and expression of zif 268 mRNA suggests that the central release of ACTH secretagogues was not affected at this time point by treatment with the GR agonist. Rather, the inhibition of ACTH release appeared to be due to a direct effect of RU28362 within the pituitary. A follow-up time-course study varied the interval (10,60 or $180 \mathrm{~min}$ ) between RU28362 pretreatment and the onset of restraint. The stress-induced increase in POMC hnRNA was completely blunted by RU28362 treatment within 10 min of treatment, although the stress induced hormone secretion, c-fos mRNA and zif268 mRNA were unaffected. The rapid inhibition of the stress-induced rise in POMC hnRNA in the anterior pituitary appears to reflect direct, GR-mediated suppression of POMC gene expression. RU28362 pretreatment 180 min before restraint onset was sufficient to suppress the stress-induced expression in the anterior pituitary gland of all three genes examined. Thus, the delayed negative feedback effects on hypothalamic-pituitary-adrenal axis activity that emerged after 180 min after glucocorticoid treatment were not evident at 60 min. Taken together, the data suggest that the inhibition of the stress-induced release of ACTH apparent within the first hour of glucocorticoid exposure is effected at the level of the pituitary gland. The delayed glucocorticoid effects evident 180 min after RU28362 treatment may include glucocorticoid actions in the brain and additional actions within the pituitary.
\end{abstract}

Treatment of rats with glucocorticoids suppresses subsequent stress-induced activity of the hypothalamo-pituitary-adrenal (HPA) axis (negative feedback). These negative feedback effects depend on multiple molecular processes at cellular locations intrinsic (paraventricular nucleus of the hypothalamus (PVN) and anterior pituitary) and perhaps extrinsic to the HPA axis $(1,2)$. However, the site specific actions and temporal sequence of glucocorticoid effects that contribute to HPA axis hormonal secretion is still not well understood. Although it is well established that glucocorticoids act on both the hypothalamus $(3-7)$ and the pituitary $(3,8,9)$ to alter subsequent HPA responsivity, the timeframe of these discrete effects has not been clearly established. Conse- quently, it remains unclear which glucocorticoid negative feedback actions are necessary and sufficient to cause inhibition of stress-induced hormone secretion at various points in time after a phasic increase in systemic glucocorticoids. To improve our understanding of the various glucocorticoid actions that contribute to negative feedback, we have adopted the strategy of examining changes in stressinduced gene expression within components of the HPA axis at various intervals after treatment with the specific glucocorticoid receptor (GR) agonist RU28362. Unlike the higher affinity corticosteroid receptor (mineralocorticoid receptor), very little GR is bound by basal corticosterone levels, and GR occupancy fluctuates with transient increases in plasma

Correspondence to: Dr Abigail B. Ginsberg, Department of Physiology, University of California, San Francisco, 513 Parnassus Avenue, Box 0444, San Francisco, CA 94143, USA (e-mail: aginsber@itsa.ucsf.edu). 
corticosteroid concentration (10). Consequently, GR is believed to be the corticosteroid receptor that primarily mediates the glucocorticoid negative feedback resulting from a phasic increase in endogenous glucocorticoid secretion (10). Although a direct regulatory role of GR at the pituitary has been well documented $(1,2,11)$, the extent to which this action is necessary for glucocorticoid inhibition of stressinduced HPA axis hormone secretion has not been carefully evaluated. The present studies explored the functional consequences of these negative feedback effects within discrete timeframes.

Exposure of rats to a wide range of stressors rapidly induces within the medial parvocellular portion of the PVN expression of a number of different genes including the $c$-fos and corticotrophin-releasing hormone $(\mathrm{CRH})$ genes $(12,13)$. The rapid induction of these genes within the PVN is a result of stress-induced alterations in the neural input and subsequent signal transduction pathway activity within these neurones. Each individual gene has a unique promoter region and associated regulatory elements, which may or may not include glucocorticoid response elements. Thus, it is possible that the expression of each gene provides a unique profile of intracellular activity and glucocorticoid signal integration. Our previous studies that examined the effects of glucocorticoids on stress-induced $c$-fos and $\mathrm{CRH}$ gene expression in the PVN support this view (14). Treatment of rats with the GR selective agonist RU28362 $60 \mathrm{~min}$ before restraint effectively suppresses the corticosterone response to restraint, and also suppresses the stress-induced expression of $\mathrm{CRH}$ hnRNA. Surprisingly, this treatment does not suppress stressinduced induction of c-fos mRNA or Fos protein. These results led us to conclude that RU28362 treatment does not surpress the stress-induced excitatory input to the PVN within 60 min of treatment. Thus, the glucocorticoid suppression of corticosterone secretion must be due to an effect downstream from the excitatory input to the PVN. This could be due to either a direct glucocorticoid effect on the $\mathrm{CRH}$ neurones and/or a direct effect on corticotrophs.

To advance this hypothesis, the present study examined the expression of stress-responsive genes in the pituitary gland to determine whether RU28362 treatment inhibits the pituitary gland response to stressful stimuli. If RU28362 suppress the secretion of adrenocorticotrophic hormone (ACTH) secretagogues [e.g. CRH and argine vasopressin (AVP)], then we would predict a suppression of stress-induced gene expression in the anterior pituitary. If instead, the inhibitory effects of RU28362 on ACTH secretion reflect direct actions on corticotrophs, RU28362 should have no effect on gene expression or will supress the expression of those genes that are directly repressed by glucocorticoids.

In this study, we examined the expression of three genes, c-fos, zif268 (also known as NGFI-A, Krox-24 or Egr-1) and pro-opiomelanocortin (POMC). We have used the quantitative real-time polymerase chain reaction (qPCR) as a sensitive quantitative measure of gene expression in both the anterior and intermediate/posterior lobes of the pituitary gland. The c-fos and POMC genes have been shown previously to be induced in the anterior pituitary gland after $30 \mathrm{~min}$ of restraint (15). Because POMC is expressed constitutively at a relatively high level, changes in POMC expression were determined by measurement of heteronuclear POMC hnRNA (hnRNA) (16). We included zif268 mRNA in this study as an immediate early gene that is rapidly induced in neural tissue by stress but, in contrast to $c-f o s$, is resistant to suppression by chronic glucocorticoid treatment (17). Although our focus is on gene expression within the corticotroph containing anterior pituitary, we also measured gene expression in the intermediate pituitary lobe. POMC expression in both the anterior and intermediate pituitary is induced by CRH (16). However, it appears that only POMC expression in the anterior pituitary is subject to direct GR-mediated glucocorticoid regulation. As we confirm in this report, very few if any GR immunopositive cells are present within the intermediate pituitary $(18,19)$.

In our initial experiments, rats were pretreated with RU28362 60 min before restraint challenge to establish the feasibility of monitoring stress-induced gene expression in the anterior pituitary with qPCR as well as determination of possible differential gene response to RU28362. In a subsequent experiment, we varied the interval $(10,60$ or $180 \mathrm{~min})$ between RU28362 treatment and the subsequent stress challenge. The very short treatment interval allowed for determination of rapid glucocorticoid effects, whereas the longer treatment interval fell within the time domain typically associated with delayed glucocorticoid negative feedback (2).

\section{Materials and methods}

\begin{abstract}
Subjects
Young adult male Sprague-Dawley rats (Harlan, Essex, UK) weighing 250$350 \mathrm{~g}$ were housed in pairs in polycarbonate tubs in a noise-proof colony room maintained under a $12: 12 \mathrm{~h} \mathrm{light/dark}$ cycle (lights on $07.00 \mathrm{~h}$ ). Standard rat chow and water were provided $a d$ lib. Animals were given at least 2 weeks to acclimatise to the colony prior to experimentation. All rats were weighed and given identification markings on the day before experimentation. Experiments were carried out between $08.00 \mathrm{~h}$ and $12.00 \mathrm{~h}$ to insure that all experiments were conducted in the circadian trough. All animal experimentation was approved by the Institutional Animal Care and Use Committee at the University of Colorado at Boulder.
\end{abstract}

\section{Drug pretreatment}

The dose of RU28362 $(150 \mu \mathrm{g} / \mathrm{kg})$ chosen for these experiments has been shown to occupy the majority of GR in brain tissue and to suppress restraintinduced corticosterone and ACTH secretion substantially (4). RU28362 (a gift of the former pharmaceutical company Roussel Uclaf, France) was dissolved in $0.9 \%$ saline containing $40 \%$ 2-hydroxypropyl-beta-cyclodextrin (HBC, H107, Research Biochemicals International, Natick, MA, USA). Rats were injected with drug or vehicle i.p. at varying timepoints before the onset of restraint stress.

\section{Restraint stress}

Rats were placed in clear Plexiglas tubes $(23.5 \mathrm{~cm}$ in length and $7 \mathrm{~cm}$ in diameter; with multiple air holes) with their tails protruding. The size of the tube restricted lateral and forward/backward movement but did not interfere with breathing. Restraint was applied in a room separate but near the homecage room.

\section{Experimental procedures}

Effect of systemic administration of RU28362 on intracellular GR localisation in the pituitary gland

GR is localised in the cytoplasm in the absence of ligand and upon binding ligand translocates to the nucleus of the cell (20). Cytoplasmic versus nuclear 
GR localisation was visually distinguished by immunohistochemistry. This experiment examined GR expression in pituitary and the extent of GR occupation by RU28362 $60 \mathrm{~min}$ after treatment. Rats were bilaterally adrenalectomised to eliminate endogenous GR ligand (corticosterone). After recovery from surgery ( 3 days), adrenalectomised rats were injected i.p. with RU28362 $(150 \mu \mathrm{g} / \mathrm{kg})$ or vehicle $(\mathrm{n}=4) ; 60$ min later rats were deeply anaesthetised with a xylazine $(20 \mathrm{mg} / \mathrm{kg})$ and ketamine $(100 \mathrm{mg} / \mathrm{kg})$ mixture and perfused trans-cardially with $400-500 \mathrm{ml} 0.01 \mathrm{M}$ phosphate-buffered saline (PBS) followed by $400-500 \mathrm{ml}$ of ice-cold $4 \%$ paraformaldehyde in $0.1 \mathrm{~m}$ PBS. The pituitary glands were removed and postfixed in $4 \%$ paraformaldehyde for $24 \mathrm{~h}$. Coronal sections $(40 \mu \mathrm{m})$ were cut on a vibratome and collected in PBS. Slices were immunostained (as described below) within 2 days after sectioning.

\section{Experiment 1: effect of treatment with RU28362 60 min prior to stress} on gene expression in the pituitary

Rats were injected i.p. with RU28362 $(150 \mu \mathrm{g} / \mathrm{kg})$ or vehicle $60 \mathrm{~min}$ before exposure to a 15-min period of restraint stress. Control rats were left undisturbed in their homecage after injection. The period of restraint was selected on the basis of time course studies which demonstrated peak expression of c-fos mRNA in the PVN at this time point (unpublished data). Immediately following the termination of restraint stress, or at an equivalent postinjection timepoint for control animals, the rats were decapitated rapidly and their pituitary glands removed. The posterior and intermediate lobes were visualised with a dissecting microscope and were separated from the anterior lobe manually using fine forceps. The two sections (anterior lobe and a posterior/intermediate lobe complex) were then flash-frozen in microfuge tubes and stored at $-80{ }^{\circ} \mathrm{C}$ until processing for PCR analysis (described below).

Experiment 2: effect of pretreatment with RU28362 10, 60 or 180 min prior to stress on gene expression in the anterior pituitary

Rats were injected i.p. with RU28362 $(150 \mu \mathrm{g} / \mathrm{kg})$ or vehicle 10,60 or $180 \mathrm{~min}$ before onset of a 15-min period of restraint stress. Control rats were injected with the vehicle and left undisturbed in their homecage for $75 \mathrm{~min}$. Immediately following the termination of restraint stress rats were rapidly decapitated, and their pituitary glands were removed, dissected, and frozen as described above. Anterior pituitary tissue was stored at $-80{ }^{\circ} \mathrm{C}$ until it was processed for PCR analysis (described below).

\section{Corticosterone radioimmunoassay}

Trunk blood was collected immediately after decapitation and the plasma was separated and stored at $-20{ }^{\circ} \mathrm{C}$. Corticosterone was measured by radioimmunoassay (4). The within and between assay coefficients of variation were $6.3 \%$ and $9.0 \%$, respectively. The detection limit was $0.5 \mu \mathrm{g} / \mathrm{dl}$ for a $20 \mu \mathrm{l}$ sample.

\section{ACTH radioimmunoassay}

Blood samples for the ACTH assay were collected into EDTA coated tubes and stored at $-80^{\circ} \mathrm{C}$. Plasma concentrations of ACTH were determined by radioimmunoassay procedures described in Nicholson et al. (21) using antiserum (rabbit antibody Rb7) courtesy of Dr Bill Engeland, University of Minnesota. The within and between assay coefficients of variation were $6.2 \%$ and $14.4 \%$, respectively. The detection limit for this assay was $15 \mathrm{pg} / \mathrm{ml}$ for a $50 \mu \mathrm{l}$ sample.

\section{GR protein immunohistochemistry}

Tissue sections were incubated overnight $\left(4{ }^{\circ} \mathrm{C}\right)$ in $0.1 \mathrm{M}$ PBS containing rabbit antiserum, $0.3 \%$ Triton-X and $1.5 \%$ normal goat serum. The GR antiserum was raised against a peptide sequence unique to a portion of the glucocorticoid receptor (22) (hGR 346-367; $1: 500$ dilution; PA1-511; Affinity Bioreagents, Golden, CO, USA). The tissue was then incubated in PBS containing biotinylated goat anti-rabbit immunoglobulin secondary antibody (1:500; Vector Laboratories, Burlingame, CA, USA) for $2 \mathrm{~h}$ and a colour precipitate was achieved using the biotin-avidin-immunoperoxidase method (ABC VectaStain Kit, Vector Laboratories). Tris buffered diaminobenzidine $(0.2 \mathrm{mg} / \mathrm{ml})$ and nickel ammonium sulphate $(6.5 \mathrm{mg} / \mathrm{ml})$ were used as chromogens. The sections were mounted onto glass microscope slides, air-dried, rinsed in distilled water, dehydrated, delipidised, and coverslipped.
Quantitative real-time polymerase chain reaction

Total RNA was isolated from pituitary tissue (23), DNase treated (DNA-free kit; Ambion, Austin, TX, USA), reverse transcribed with use of random primers into cDNA, and amplified using q-PCR methodology (24) with aid of the Quantitect SYBR Green PCR Kit (Qiagen, Valencia, CA, USA). Complementary DNA sequences for rat $c$-fos mRNA (Accession no. X06769), zif-268 mRNA (Accession no.012551), POMC hnRNA (Accession no. J00759), and GAPDH (Accession no. M17701) were obtained from GenBank at the National Center for Biotechnology Information (NCBI; http://www.ncbi.nlm.nih.gov). Primer sequences are as follows: $c$-fos mRNA (forward: 5'-CTTCCTTTGTCTTCACCTACC-3'; reverse: 5'-CCTTCTCTG ACTGCTCACA-3'; 110 bp product), zif-268 mRNA (forward: 5'-TCACTC ACCCACCATGGACAAC-3'; reverse: 5'-TCAGCAGCATCATCTCCTC CAG-3'; 53 bp product), POMC hnRNA (forward: 5'-TTGGGTGGAAG ATGGCAC-3'; reverse: 5'-GATGCAAGCCTGTAGGGA-3'; 132 bp product, spans intron A and exon 2) and GAPDH (forward: 5'-GTTTGTGAT GGGTGTGAACC-3'; reverse: 5'-TCTTCTGAGTGGCAGTGATG-3'; $162 \mathrm{bp}$ product). Primer specificity was verified by melt curve analysis. Relative gene expression was determined using the $2^{-\Delta \Delta C t}$ method $(24,25)$. All values for gene expression following $\mathrm{qPCR}$ analysis are expressed as relative to the housekeeping gene GAPDH and referred to as 'relative expression.' Values for experiment two have been expressed as a percent of the basal value for nonstressed, vehicle-treated controls in order to illustrate stress-induced increases.

\section{Statistical analysis}

Statistical analyses were conducted using the StatView statistical analysis programme (SAS Institute, Cary, NC, USA). Data were analysed using ANOVA followed by Fisher's post-hoc tests. Experiment 1 included several cohorts of rats, therefore cohort was included as a covariate in the analysis. Statistical significance level was a priori set at $\mathrm{P}<0.05$. Summary data presented in graphs and texts are the group means \pm SEM.

\section{Results}

Effect of systemic administration of RU28362 on intracellular $G R$ localisation in the pituitary gland

In tissue from vehicle-treated adrenalectomised rats, the GR immunostaining was weakly distributed throughout the cell (Fig. 1). By contrast in tissue from rats treated with RU28362, GR immunostaining was strong, predominantly nuclear, and present in cells scattered throughout the anterior and posterior lobe of the pituitary, but almost completely absent in the intermediate lobe (Fig. 1). The strong GR nuclear immunostaining of R28362 treated rats suggests that this dose of RU28362 effectively occupied GR in the anterior pituitary.

\section{Experiment 1: effects of pretreatment with RU28362 $60 \mathrm{~min}$ prior to stress on pituitary hormone secretion and gene expression in anterior lobe versus posterior/intermediate lobes of the pituitary}

This experiment examined the effect of stress and RU28362 pretreatment on gene expression in both the anterior lobe (three cohorts) and the combined intermediate and posterior lobes of the pituitary (one cohort; $n=4-5$ rats per treatment group per cohort).

Plasma hormone concentrations (Fig. 2)

There was a substantial increase in ACTH and corticosterone 15 min after restraint onset in control rats. This increase was 

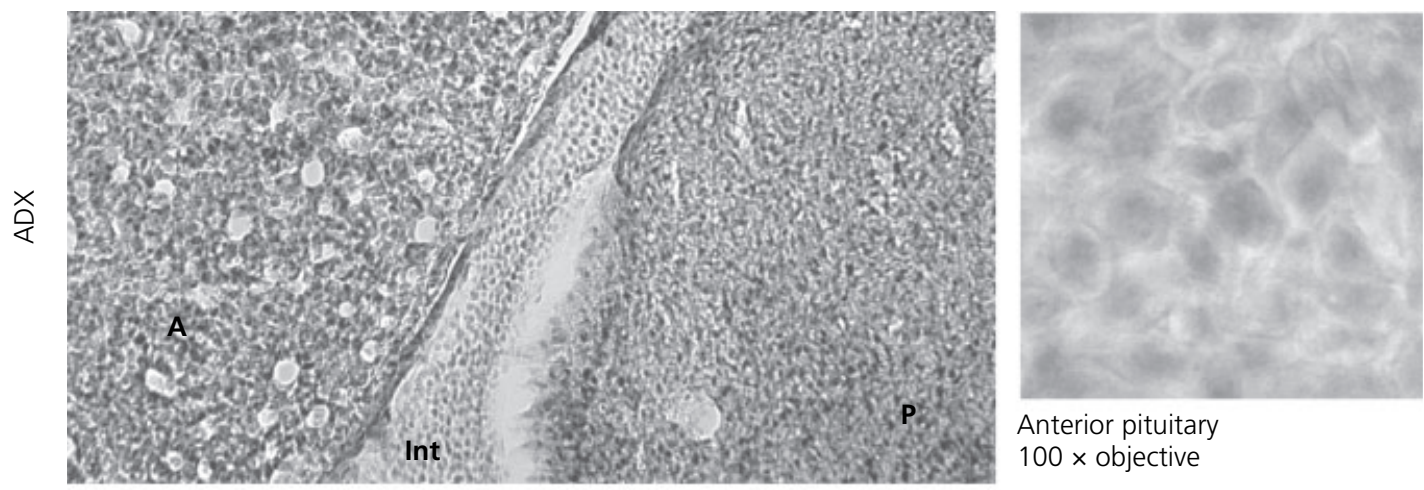

Anterior pituitary

$100 \times$ objective
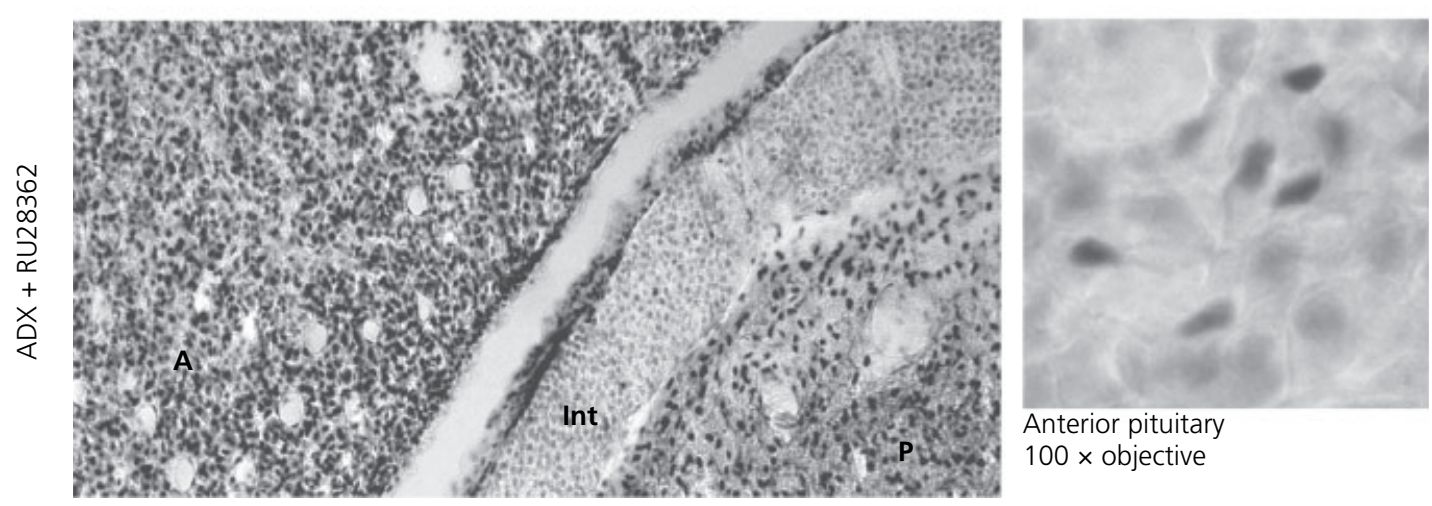

Fig. 1. Glucocorticoid receptor (GR) is expressed and activated by RU28362 in anterior and posterior lobes of the pituitary, but not in the intermediate lobe. The top left panel portrays the anterior (A), intermediate (Int), and posterior (P) lobes of the pituitary immunostained for GR in an adrenalectomised rat $60 \mathrm{~min}$ following vehicle treatment $(\times 20$ objective). In the absence of endogenous or exogenous glucocorticoids, the predominantly cytoplasmic localisation of GR results in diffuse immunoreactivity at higher magnification (top right panel; $\times 100$ objective). The lower panels depict GR immunostaining $1 \mathrm{~h}$ after i.p. injection of RU28362 $(150 \mu \mathrm{g} / \mathrm{kg})$ in an adrenalectomised rat. Note the punctate staining representing nuclear GR localisation in anterior and posterior pituitary. Very little GR immunostaining is evident in the intermediate lobe.

significantly inhibited by RU28362 treatment 60 min before restraint onset. Thus, there was a main effect of stress on both ACTH $[\mathrm{F}(26,27)=9.120, \quad \mathrm{P}=0.01]$ and corticosterone $[\mathrm{F}(26,27)=113.94, \mathrm{P}<0.001]$ secretion, a main effect of drug on $\mathrm{ACTH}[\mathrm{F}(26,27)=30.1, \mathrm{P}<0.01]$ and corticosterone $[\mathrm{F}(26,27)=101.29, \mathrm{P}<0.01]$ secretion, and a stress by drug interaction effect on $\mathrm{ACTH}[\mathrm{F}(26,27)=4.57, \mathrm{P}=0.05]$ and corticosterone $[\mathrm{F}(26,27)=77.19, \mathrm{P}<0.01]$ secretion.

\section{Gene expression in the pituitary (Fig. 3)}

The expression of all three genes examined (c-fos mRNA, zif268 mRNA, POMC hnRNA) was induced by $15 \mathrm{~min}$ restraint stress in both the anterior pituitary and in the intermediate/posterior pituitary. There was a main effect of stress on $c$-fos mRNA in the anterior $[\mathrm{F}(26,27)=50.4$, $\mathrm{P}<0.01)$ and intermediate/posterior pituitary $[\mathrm{F}(26,28)=39.6, \mathrm{P}<0.01)]$, a main effect of stress on zif268 mRNA in the anterior $[\mathrm{F}(26,27)=26.6, \mathrm{P}<0.01]$ and intermediate/posterior pituitary $[\mathrm{F}(26,28)=23.2$, $\mathrm{P}<0.001]$, and a main effect of stress on POMC hnRNA in the anterior $[\mathrm{F}(26,27)=16.2 \mathrm{P}<0.01]$ and intermediate/ posterior pituitary $[\mathrm{F}(26,28)=73.5, \mathrm{P}<0.01]$. Treatment with RU28362 $60 \mathrm{~min}$ before restraint onset selectively inhibited stress-induced and basal POMC hnRNA in the anterior pituitary $[\mathrm{F}(26,29)=10.5, \mathrm{P}<0.01]$.
Experiment 2: effect of pretreatment with RU28362 10,60 or 180 min prior to stress on pituitary hormone secretion and gene expression in the anterior pituitary

This second experiment examined whether a shorter (10 min) or longer $(180 \mathrm{~min})$ intervals between drug treatment and stress would have the same effect on gene expression in the anterior pituitary as that seen in the previous experiment with 60 min pretreatment.

\section{Plasma hormone concentrations (Fig. 4)}

As in the previous experiment, pretreatment with RU28362 had an overall suppressive effect on stress-induced ACTH $[\mathrm{F}(26,30)=9.0, \quad \mathrm{P}<0.01]$ and corticosterone $[\mathrm{F}(26,30)=5.7, \mathrm{P}<0.01]$ secretion. Post-hoc tests indicated that there was no significant effect of drug on hormone secretion with the $10 \mathrm{~min}$ pretreatment interval, a partial suppression with $60 \mathrm{~min}$ pretreatment (statistically significant for corticosterone, but not ACTH secretion) and substantial, significant suppression with $180 \mathrm{~min}$ pretreatment $(\mathrm{P}<0.001)$.

\section{Gene expression in the anterior pituitary (Fig. 5)}

Again there was a significant induction of c-fos mRNA, zif268 mRNA and POMC hnRNA in the anterior pituitary 

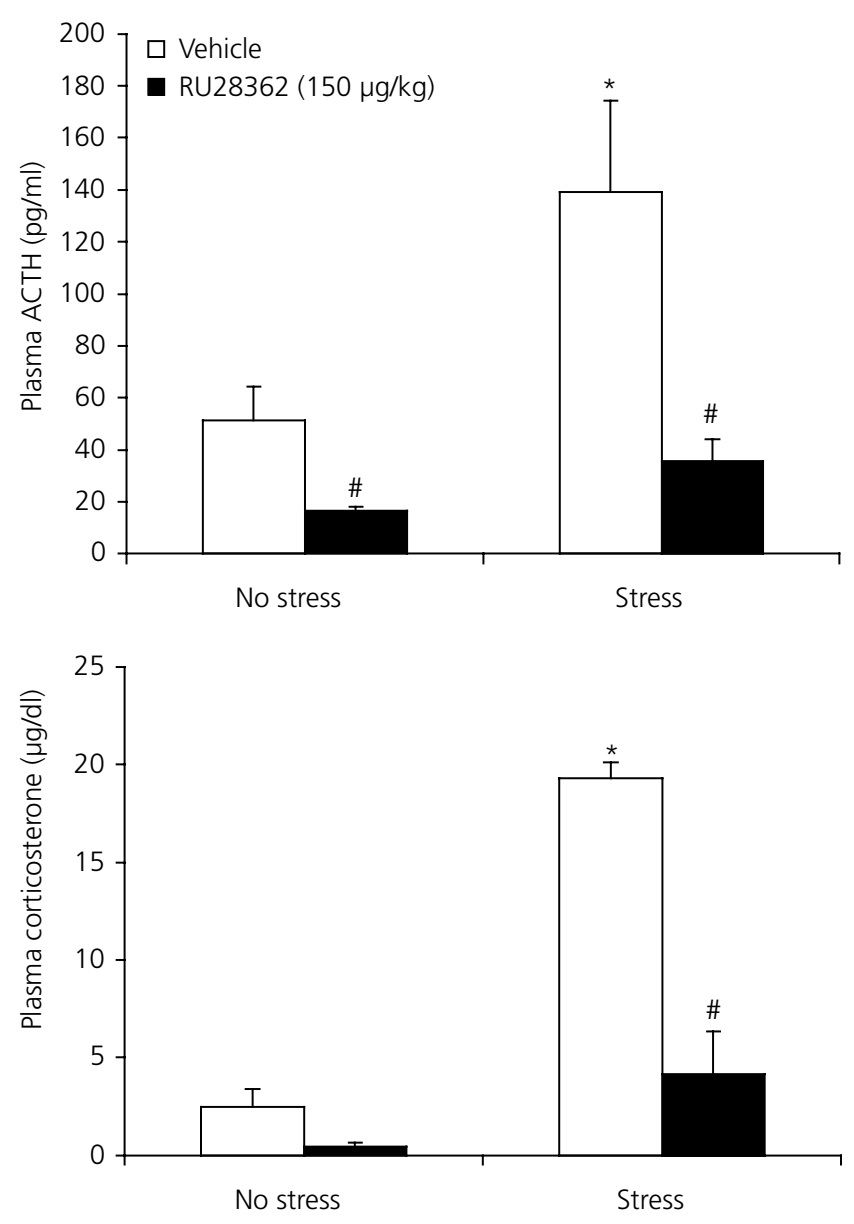

FIG. 2. RU28362 pretreatment $(60 \mathrm{~min})$ inhibits stress-induced increases in hormone secretion. Plasma hormone concentrations in rats treated with RU28362 (150 $\mu \mathrm{g} / \mathrm{kg}$ i.p.) or vehicle $60 \mathrm{~min}$ before exposure to $15 \mathrm{~min}$ of restraint stress; controls were left undisturbed in their home cage (no stress). $* \mathrm{P}<0.05$ compared to no stress rats in the same drug condition; $\# \mathrm{P}<0.05$ compared to vehicle-treated rats in the same stress condition; $\mathrm{n}=12-15$. ACTH, Adrenocorticotrophic hormone.

gland within 15 min of restraint. Varying the interval between RU28362 pretreatment and the onset of restraint stress revealed a delayed effect of GR receptor activation on $c-f o s$ and zif268 mRNA compared to POMC hnRNA. Thus, overall, there was no main effect of the pretreatment interval or drug treatment on $c-f o s$ expression. However, there was a significant interaction between the two factors $[\mathrm{F}(26,30)=5.9, \mathrm{P}<0.01)$. Further analysis revealed that there was no significant effect of RU28362 pretreatment on stress-induced $c$-fos mRNA expression after the $10 \mathrm{~min}$ and $60 \mathrm{~min}$ pretreatment interval. However, there was an almost complete blunting of stress-induced $c$-fos mRNA expression after the $60 \mathrm{~min}$ pretreatment interval. The pattern of zif 268 mRNA expression across treatments was similar to that for c-fos mRNA, with no inhibitory influence of RU28362 pretreatment except with the 180 min pretreatment time. Fisher's post-hoc analysis revealed that at the $10 \mathrm{~min}$ pretreatment interval, RU28362 pretreatment actually caused a significant up-regulation of stress-induced zif-268 mRNA expression $(\mathrm{P}=0.02)$. In the case of POMC hnRNA expres- sion, RU28362 pretreatment dramatically blunted stressinduced POMC hnRNA expression at all three pretreatment intervals $[\mathrm{F}(26,30)=23.9, \mathrm{P}<0.01]$.

\section{Discussion}

In the present study, we found that the psychological stressor, restraint (31), produced a rapid (within $15 \mathrm{~min}$ ) induction of POMC hnRNA, c-fos mRNA and zif268 mRNA in both the anterior and intermediate/posterior pituitary gland. Pretreatment with the GR selective agonist, RU28362 $60 \mathrm{~min}$ before the onset of stress inhibited the release of stress-induced ACTH (experiment 1) and corticosterone (experiments 1 and 2), and the induction of POMC hnRNA (experiments 1 and 2). By contrast, the drug treatment did not affect the stress-induced c-fos mRNA or zif268 mRNA in anterior or intermediate/ posterior pituitary. Nor did it inhibit the stress-induced expression of POMC hnRNA in the intermediate/posterior pituitary. Consequently, we conclude that administration of RU28362 60 min before stress does not inhibit the stressinduced intercellular signals to the pituitary that are responsible for c-fos or zif268 gene induction throughout the pituitary. Nor does it inhibit the signals which lead to POMC gene induction in the intermediate lobe.

The conclusion that activation of GR $60 \mathrm{~min}$ prior to stress does not affect the stress-induced signals to the pituitary gland has several implications. First, the inhibition of stressinduced ACTH and corticosterone secretion $60 \mathrm{~min}$ after RU28362 treatment must reflect a direct glucocorticoid effect in the anterior pituitary gland. Second, activated GR directly inhibits POMC gene induction in corticotrophs, but not in melanotrophs. Third, the activated GR does not inhibit $c$-fos or zif268 gene induction directly in the pituitary. We discuss these implications below.

\section{RU28362 suppression of stress-induced ACTH and corticosterone secretion}

We have previously reported that treatment with RU28362 or corticosterone 60 min prior to restraint stress suppresses the ACTH and corticosterone response, but not the $c$-fos mRNA response in the PVN (4). The conclusion drawn from these studies was that stress-induced neural inputs to the PVN were not inhibited within $60 \mathrm{~min}$ after glucocorticoid treatment. The results from this study extend those findings by suggesting that administration of RU28362 60 min before stress also does not inhibit stress-induced CRH/AVP secretion from PVN neurones.

It is possible that multiple hormonal signals converge on the anterior pituitary gland within $15 \mathrm{~min}$ of restraint stress onset, and that the $c$-fos, zif268 and POMC genes respond differently to these signals. In this case, RU28362 pretreatment may induce a selective inhibition of a stress-induced signal that induces POMC but fails to induce $c$-fos or zif268. CRH is the stress-induced signal that is most likely responsible for the POMC gene induction seen in both the anterior and intermediate/posterior pituitary. CRH is a potent stimulus of POMC induction in both corticotrophs and melanotrophs, whereas AVP has minimal effects on POMC gene 

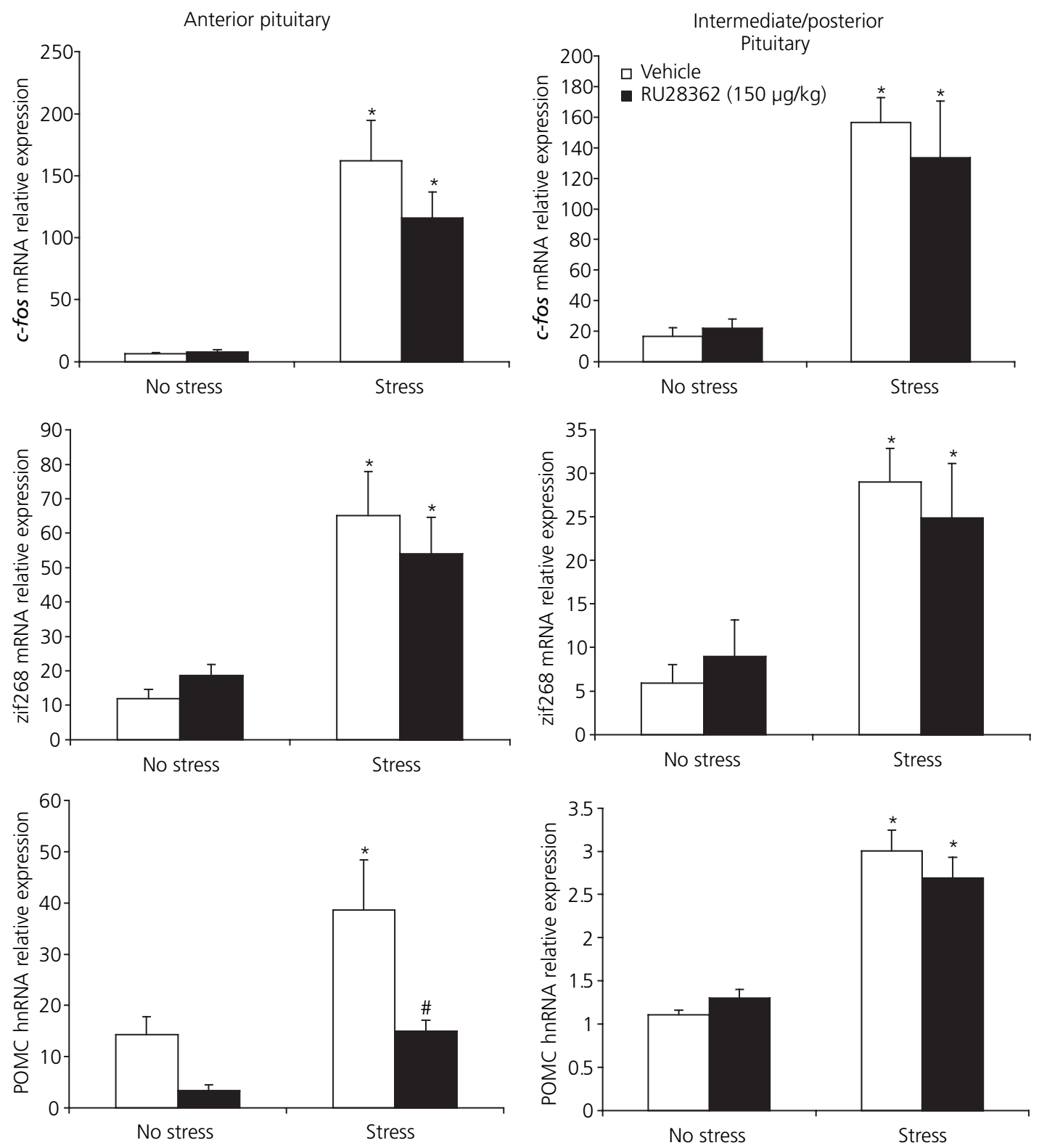

FIG. 3. RU28362 pretreatment (60 min) selectively inhibits stress-induced pro-opiomelanocortin (POMC) hnRNA expression in the anterior pituitary. The expression of $c$-fos mRNA, zif-268 mRNA and POMC hnRNA was measured by qPCR in the anterior and intermediate/posterior lobes of the pituitary gland of individual rats. Rats were treated with RU28362 (150 $\mu \mathrm{g} / \mathrm{kg}$ i.p.) or vehicle and exposed $1 \mathrm{~h}$ later to 15 min of restraint or left undisturbed in their home cage (no stress). ${ }^{*} \mathrm{P}<0.05$ compared to no stress rats in the same drug condition; \#P $<0.05$ compared to vehicle-treated rats in the same stress condition; anterior pituitary, $\mathrm{n}=12-15$; posterior pituitary, $\mathrm{n}=4-5$.

promoter activity in corticotrophs $(26,32)$. CRH has also been shown to induce $c$-fos mRNA in transformed corticotrophs (33). Thus, it is likely that at least a substantial portion of the stress-induced gene expression observed in this study was due to CRH stimulation of corticotrophs. On the other hand, there is the possibility that other cell types in the anterior pituitary may be activated by other stress-induced secretagogues that are insensitive to glucocorticoid action. Immediate early gene expression in these other cells may then mask a selective reduction in corticotrophs. For example, there are substantially more lactotrophs than corticotrophs in the anterior pituitary and these cells are probably activated by acute stress since plasma prolactin levels often increase with stress (34). The secretagogue responsible for stress-induced prolactin secretion is unknown, but is probably not prolactinreleasing peptide (35) or decreased hypophyseal dopamine (36). Although the expression of POMC hnRNA in the anterior pituitary presented here is undoubtedly specific to corticotrophs, further studies will be necessary to identify the phenotype of other pituitary cells that may express immediate early genes during acute stress.

Given the overall pattern of gene expression 60 min after RU28362 treatment, we believe that a straightforward conclusion is that there was no suppression of any major stressinduced signals (e.g. CRH) to the anterior pituitary, and that the selective suppression of POMC hnRNA reflects a direct 

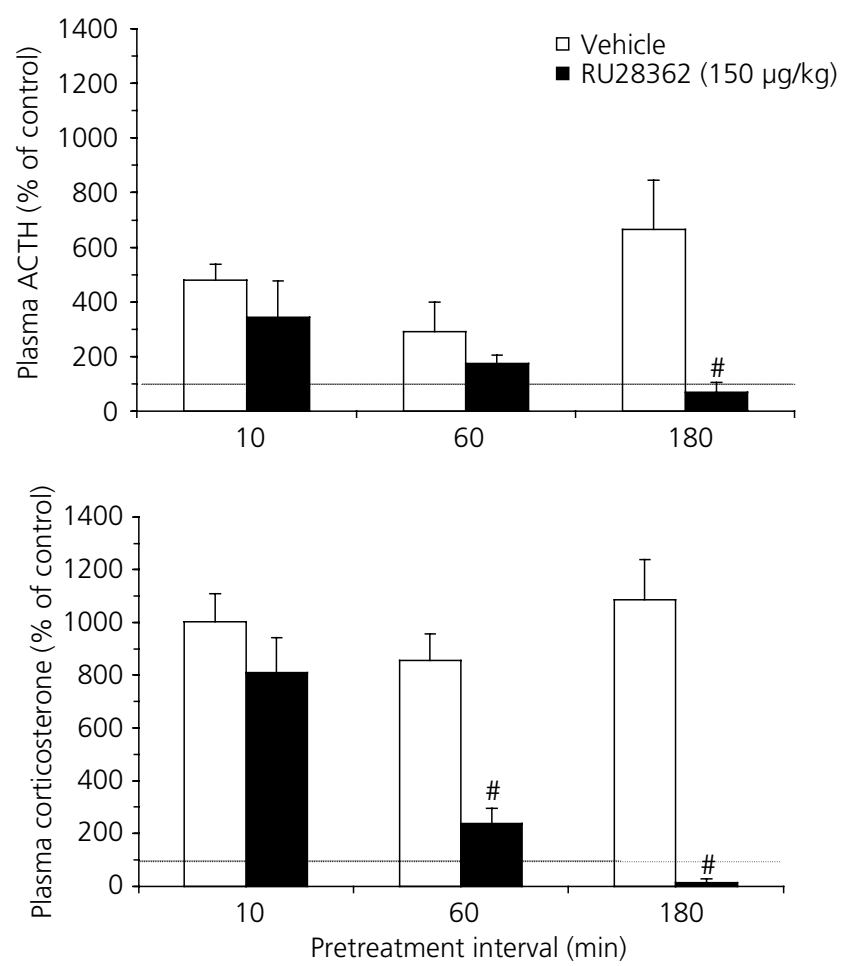

Fig. 4. Effects of RU28362 given at varying pretreatment intervals on stressinduced hormone secretion. Plasma hormone concentrations in rats treated with RU28362 $(150 \mu \mathrm{g} / \mathrm{kg}$ i.p.) or vehicle 10,60 or $180 \mathrm{~min}$ before onset of 15 min of restraint. A nonstress control group of rats was injected with vehicle $75 \mathrm{~min}$ prior to blood collection. The values are presented as a percentage of the mean value from this group (value represented by horizontal line). $\# \mathrm{P}<0.05$ compared to vehicle-treated rats in the same stress condition; $n=4-6$. ACTH, Adrenocorticotrophic hormone.

inhibitory effect of activated GR on POMC gene induction. The apparent lack of effect of 60 min RU28362 pretreatment on $\mathrm{CRH}$ neurone secretion inferred in this study cannot be attributed to a failure of the drug to cross the blood brain barrier because we previously found that RU28362 pretreatment not only occupied receptors centrally but also completely blocked stress-induced CRH hnRNA in the PVN (4). If, within this 60 min time-frame RU28362 does not block CRH secretion, then the inhibition of ACTH secretion must be due to a direct glucocorticoid action at the level of the anterior pituitary. There is surprisingly little previously published data that addresses whether a direct effect at the level of the pituitary is necessary to suppress hormone secretion. In support of this finding, the acute $(<2 \mathrm{~h})$ effects of systemic glucocorticoid treatment on hypophyseal portal vein $\mathrm{CRH}$ levels have not been explored $(37,38)$. However, there is one study that demonstrated rapid effects of glucocorticoids $(<1 \mathrm{~h})$ on stress-induced changes in $\mathrm{CRH}$ bioactivity in rat hypothalamic tissue (3). The extent to which those changes in hypothalamic $\mathrm{CRH}$ content reflect altered secretion and/or synthesis is unknown. Studies examining the effects of glucocortioid placement directly in the PVN on HPA axis hormone secretion routinely used longterm steroid implantation. One study that administered dexamethasone acutely into the PVN via bilateral microinjection observed suppressed stress-induced ACTH secretion 3.5 h later (28).
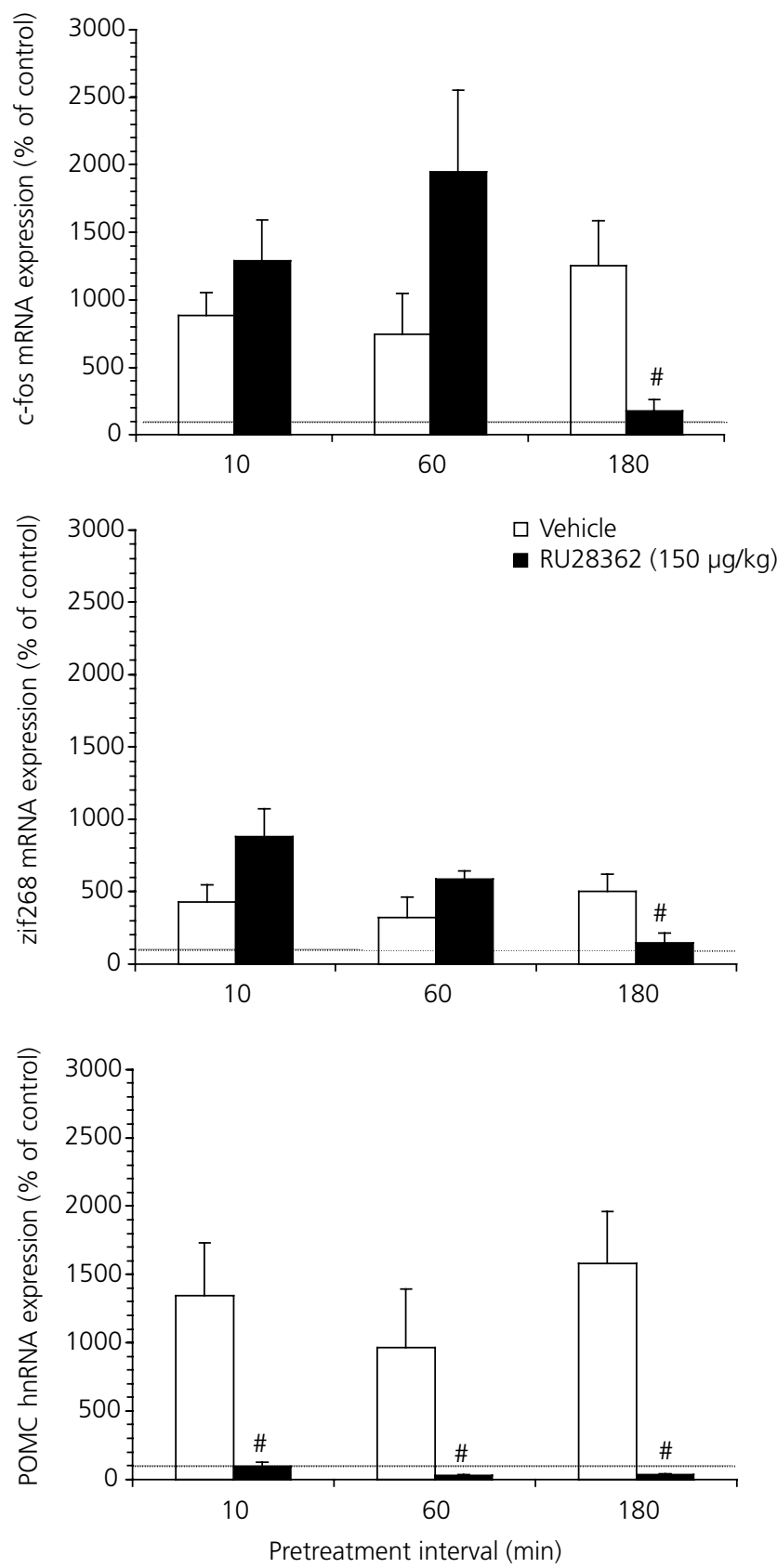

FIG. 5. Effects of RU28362 given at varying times prior to the induction of stress-induced gene expression in the anterior pituitary. The expression of c-fos mRNA, zif-268 mRNA and pro-opiomelanocortin (POMC) hnRNA was measured by qPCR in the anterior pituitary gland of individual rats that were treated with RU28362 $(150 \mu \mathrm{g} / \mathrm{kg}$ i.p.) or vehicle 10,60 or $180 \mathrm{~min}$ before onset of $15 \mathrm{~min}$ of restraint. A nonstress control group of rats was injected with vehicle $75 \mathrm{~min}$ prior to blood collection. The values are presented as a percentage of the mean value from this group (value represented by horizontal line). \#P $<0.05$ compared to vehicle-treated rats in the same stress condition; $\mathrm{n}=4-6$.

The lack of a significant suppression of stress-induced $\mathrm{ACTH}$ and corticosterone secretion with the short $(10 \mathrm{~min})$ glucocorticoid pretreatment time suggests that the suppression seen after $60 \mathrm{~min}$ of pretreatment may be due to a negative feedback mechanism that requires some time to develop (i.e. a mechanism distinct from fast feedback) $(2,30)$. 
Other studies have described fairly fast acting (within 1-2 h) inhibitory effects of glucocorticoids on ACTH secretion from isolated corticotrophs, AtT20 cells, or AtT20 cells cocultured with folliculo-stellate cells $(8,9,39)$.

The inhibitory effects of RU28362 on stress-induced hormone secretion were more marked after 180 min than after $60 \mathrm{~min}$. This $180 \mathrm{~min}$ treatment interval is probably sufficient for the development of multiple glucocorticoid effects that underly delayed negative feedback (2). Thus, the longer treatment interval resulted in extensive inhibition of the induction of all three genes examined; thus, we cannot infer at this time-point whether inhibition of ACTH was due to a direct action at the anterior pituitary gland and/or an inhibition of stimulatory input to the anterior pituitary gland. Additional studies are required to determine whether glucocorticoids functionally inhibit stress-induced HPA axis hormone secretion via direct actions at the hypothalamus and/or pituitary after $180 \mathrm{~min}$ of treatment.

\section{$R U 28362$ regulation of gene transcription}

The suppression of stress-induced POMC hnRNA in the anterior pituitary gland appears to be a result of a direct GR mediated inhibitory effect on gene expression. The POMC gene has a well characterised negative glucocorticoid response element (GRE) associated with its promoter region (40). Homodimerisation of GR is essential for glucocorticoid suppression of POMC transcription, as GR mutant mice that are not able to form GR homodimers $\left(\mathrm{GR}^{\mathrm{dim}}\right)$ have increased POMC expression similar to mice that are completely GR deficient (41). Also consistent with a direct glucocorticoid inhibitory effect on POMC expression is the fact that it was evident in this study with only $10 \mathrm{~min}$ of RU28362 treatment prior to stress onset.

The lack of effect of RU28362 on stress-induced POMC expression in the intermediate lobe also strongly suggests that the glucocorticoid suppression of POMC in the anterior lobe is GR dependent. As confirmed by this study, other studies have noted that melanotrophs express very few, if any GR $(18,19)$. The intermediate lobe may receive direct stimulatory input from $\mathrm{CRH}$ neurones and inhibitory input from dopaminergic neurones, and alteration of both of those inputs may be responsible for stress-induced activation of melanotrophs $(32,42)$. By contrast to the anterior pituitary, stress-induced POMC induction in the intermediate lobe is not suppressed by glucocorticoids. Previous studies have also found that long-term manipulation of glucocorticoid levels (e.g. by adrenalectomy and glucocorticoid replacement) leads to an increase and decrease in POMC expression, respectively, in the anterior pituitary but not the intermediate pituitary gland (43). Moreover, stress or $\mathrm{CRH}$-induced increases in plasma alpha-MSH are not suppressed by dexamethasone treatment, whereas plasma ACTH levels are $(44,45)$. The inability of glucocorticoids to regulate POMC expression in the intermediate lobe due to the lack of GR expression in melanotropes is also consistent with the fact that intermediate lobe POMC expression is normal in GRdeficient mice (41).

GR activation within corticotrophs may lead to a rapid and direct suppression of the POMC gene and a delayed indirect suppression of $c$-fos and zif268 genes. The rapid suppression of the POMC gene is likely, as discussed above, to be via a negative GRE. Glucocorticoid response elements have not been identified within the promoter regions of the $c$-fos and zif268 genes (46). However, activated GR may alter the expression of another gene(s) and the subsequent increase or decrease in that gene's protein product 180 min later may result in suppressed $c$-fos and zif268 gene induction.

More long-term glucocorticoid treatments (several days of corticosterone pellet implants) have been shown to suppress stress-induced c-fos in PVN (17, 47, 48). Interestingly, one study found that stress-induced rise in zif268 expression in the PVN was not suppressed after chronic glucocorticoid treatment (17). If the inhibition of zif268 mRNA expression in the anterior pituitary seen in this study reflects action of RU28362 within those cells, there may be phenotypic differences in the ability of glucocorticoids to suppress this gene. On the other hand, the fact that the stress-induced increase in zif268 mRNA was suppressed in our study may indicate that the stress-induced input to the anterior pituitary is reduced within $180 \mathrm{~min}$ of glucocorticoid treatment. We also note that there was a statistically significant increase in stress-induced zif $268 \mathrm{mRNA}$ in the anterior pituitary of rats injected with RU28362 10 min before stress onset compared to vehicle injected rats. It will be important to see if this unexpected finding is reproduced in subsequent studies because it may represent a transient enhancer function of GR on zif268 gene expression.

In conclusion, by observing differential effects of the GR selective agonist RU28362 on stress-induced gene expression in the pituitary, we are able to make some inferences about the site of action and processes that underlie the functional negative feedback effects present. Within $60 \mathrm{~min}$ of RU28362 treatment, we conclude that stress-induced ACTH secretion is inhibited due to a direct GR-mediated effect within the anterior pituitary. This inhibitory effect is independent of signal transduction pathways leading to stress-induced immediate early gene ( $c$-fos and zif268) induction. This effect is not evident within $10 \mathrm{~min}$ of glucocorticoid treatment. More extensive inhibitory effects emerge 180 min after RU28362 treatment, and these may include direct actions within the anterior pituitary, as well as actions in the brain controlling the stress-induced signals that converge on the anterior pituitary.

\section{Acknowledgements}

This work was supported by United States Public Health Service Grants MH62456 and MH65977.

Accepted 27 October 2005

\section{References}

1 Dallman M, Akana S, Cascio C, Darlington D, Jacobson L, Levin $\mathrm{N}$. Regulation of ACTH secretion: variations on a theme of $\mathrm{B}$. Recent Prog Horm Res 1987; 43: 113-173.

2 Keller-Wood ME, Dallman MF. Corticosteroid inhibition of ACTH secretion. Endocr Rev 1984; 5: 1-24.

3 Buckingham JC, Hodges JR. The influence of some neurotransmitter substances and drugs on the secretion of corticotrophin releasing 
hormone by the rat hypothalamus in vitro [proceedings]. $J$ Physiol 1979; 290: 40P-41P.

4 Ginsberg AB, Campeau S, Day HE, Spencer RL. Acute glucocorticoid pretreatment suppresses stress-induced hypothalamic-pituitary-adrenal axis hormone secretion and expression of corticotropinreleasing hormone hnRNA but does not affect c-fos mRNA or fos protein expression in the paraventricular nucleus of the hypothalamus. J Neuroendocrinol 2003; 15: 1075-1083.

5 Jones MT, Hillhouse EW. Structure-activity relationship and the mode of action of corticosteroid feedback on the secretion of corticotrophin-releasing factor (corticoliberin). J Steroid Biochem 1976; 7: 1189-1202.

6 Keller-Wood ME, Shinsako J, Dallman MF. Feedback inhibition of adrenocorticotropic hormone by physiological increases in plasma corticosteroids in conscious dogs. J Clin Invest 1983; 71: 859-866.

7 Kovacs KJ, Makara GB. Corticosterone and dexamethasone act at different brain sites to inhibit adrenalectomy-induced adrenocorticotropin hypersecretion. Brain Res 1988; 474: 205-210.

8 Dayanithi G, Antoni FA. Rapid as well as delayed inhibitory effects of glucocorticoid hormones on pituitary adrenocorticotropic hormone release are mediated by type II glucocorticoid receptors and require newly synthesized messenger ribonucleic acid as well as protein. Endocrinology 1989; 125: 308-313.

9 Shipston M. . Mechanism(s) of early glucocorticoid inhibition of adrenocorticotropin secretion from anterior pituitary corticotropes. Trends Endocrinol Metab 1995; 6: 261-266.

10 de Kloet E, Oitzl M, Joels M. Functional implications of brain corticosteroid receptor diversity. Cell Mol Neurobiol 1993; 13: 433-455.

11 de Kloet ER, Vreugdenhil E, Oitzl M, Joels M. Brain corticosteroid receptor balance in health and disease. Endocr Rev 1998; 19: 269301.

12 Honkaniemi J, Kononen J, Kainu T, Pyykonen I, Pelto-Huikko M. Induction of multiple immediate early genes in rat hypothalamic paraventricular nucleus after stress. Brain Res Mol Brain Res 1994; 25: $234-241$

13 Kovacs KJ, Sawchenko PE. Regulation of stress-induced transcriptional changes in the hypothalamic neurosecretory neurons. J Mol Neurosci 1996; 7: 125-133.

14 Ginsberg A, O'Connor KA, Spencer RL. Negative feedback effects of glucocortioid receptor agonist RU28362 on stress-induced gene expression in the PVN and pituitary. Abstract Viewer/Itinerary Planner. Washington, DC: Society for Neuroscience, 2003: program no. 28217.

15 Autelitano DJ. Stress-induced stimulation of pituitary POMC gene expression is associated with activation of transcription factor AP-1 in hypothalamus and pituitary. Brain Res Bull 1998; 45: 75-82.

16 Autelitano DJ, van den Buuse M. Concomitant up-regulation of proopiomelanocortin and dopamine D2-receptor gene expression in the pituitary intermediate lobe of the spontaneously hypertensive rat. J Neuroendocrinol 1997; 9: 255-262.

17 Umemoto S, Kawai Y, Ueyama T, Senba E. Chronic glucocorticoid administration as well as repeated stress affects the subsequent acute immobilization stress-induced expression of immediate early genes but not that of NGFI-A. Neuroscience 1997; 80: 763-773.

18 McGimsey WC, Cidlowski JA, Stumpf WE, Sar M. Immunocytochemical localization of the glucocorticoid receptor in rat brain, pituitary, liver, and thymus with two new polyclonal antipeptide antibodies. Endocrinology 1991; 129: 3064-3072.

19 Ozawa H, Ito T, Ochiai I, Kawata M. . Cellular localization and distribution of glucocorticoid receptor immunoreactivity and the expression of glucocorticoid receptor messenger RNA in rat pituitary gland. A combined double immunohistochemistry study and in situ hybridization histochemical analysis. Cell Tissue Res 1999; 295: 207-214.

20 Baumann CT, Lim CS, Hager GL. Intracellular localization and trafficking of steroid receptors. Cell Biochem Biophys 1999; 31: 119127.

21 Nicholson WE, Davis DR, Sherrel BJ, Orth DN. Rapid radioimmunoassay for corticotropin in unextracted human placenta. Clin Chem 1984; 30: 259-265.

22 Cidlowski JA, Bellingham DL, Powell-Oliver FE, Lubahn DB, Sar M. Novel antipeptide antibodies to the human glucocorticoid receptor. recognition of multiple receptor forms in vitro and distinct localization of cytoplasmic and nuclear receptors. Mol Endocrinol 1990; 4: 1427-1437.

23 Chomczynski P, Sacchi N. . Single-step method of RNA isolation by acid guanidinium thiocyanate-phenol-chloroform extraction. Anal Biochem 1987; 162: 156-159.

24 Livak KJ, Schmittgen TD. Analysis of relative gene expression data using real-time quantitative PCR and the 2(-Delta Delta C(T)) method. Methods 2001; 25: 402-408.

25 Pfaffl MW. A new mathematical model for relative quantification in real-time RT-PCR. Nucleic Acids Res 2001; 29: E45.

26 Aoki Y, Iwasaki Y, Katahira M, Oiso Y, Saito H. Regulation of the rat proopiomelanocortin gene expression in AtT-20 cells. II. Effects of the pituitary adenylate cyclase-activating polypeptide and vasoactive intestinal polypeptide. Endocrinology 1997; 138: 1930-1934.

28 Feldman S, Weidenfeld J. Further evidence for the central effect of dexamethasone at the hypothalamic level in the negative feedback mechanism. Brain Res 2002; 958: 291-296.

30 Hinz B, Hirschelmann R. Rapid non-genomic feedback effects of glucocorticoids on CRF-induced ACTH secretion in rats. Pharm Res 2000; 17: 1273-1277.

31 Dayas CV, Buller KM, Crane JW, Xu Y, Day TA. Stressor categorization: acute physical and psychological stressors elicit distinctive recruitment patterns in the amygdala and in medullary noradrenergic cell groups. Eur J Neurosci 2001; 14: 1143-1152.

32 Autelitano DJ, Blum M, Lopingco M, Allen RG, Roberts JL. Corticotropin-releasing factor differentially regulates anterior and intermediate pituitary lobe proopiomelanocortin gene transcription, nuclear precursor RNA and mature mRNA in vivo. Neuroendocrinology 1990; 51: 123-130.

33 Boutillier AL, Sassone-Corsi P, Loeffler JP. The protooncogene c-fos is induced by corticotropin-releasing factor and stimulates proopiomelanocortin gene transcription in pituitary cells. Mol Endocrinol 1991; 5: 1301-1310.

34 Freeman ME, Kanyicska B, Lerant A, Nagy G. Prolactin. structure, function, and regulation of secretion. Physiol Rev 2000; 80: 15231631.

35 Morales T, Hinuma S, Sawchenko PE. Prolactin-releasing peptide is expressed in afferents to the endocrine hypothalamus, but not in neurosecretory neurones. $J$ Neuroendocrinol 2000; 12: 131-140.

36 Minamitani N, Minamitani T, Lechan RM, Bollinger-Gruber J, Reichlin S. Paraventricular nucleus mediates prolactin secretory responses to restraint stress, ether stress, and 5-hydroxy-L-tryptophan injection in the rat. Endocrinology 1987; 120: 860-867.

37 Plotsky PM, Otto S, Sapolsky RM. Inhibition of immunoreactive corticotropin-releasing factor secretion into the hypophysial-portal circulation by delayed glucocorticoid feedback. Endocrinology 1986; 119: $1126-1130$.

38 Fink G. Mechanisms of negative and positive feedback of steroids in the hypothalamic-pituitary system. In Bittar EE, Bittar N, eds. Principles of Medical Biology, Vol. 10A: Molecular and Cellular Endocrinology. Greenwich. CT: JAI Press, 1997.

39 Tierney T, Christian HC, Morris JF, Solito E, Buckingham JC. Evidence from studies on co-cultures of TtT/GF and AtT20 cells that Annexin 1 acts as a paracrine or juxtacrine mediator of the early inhibitory effects of glucocorticoids on ACTH release. $J$ Neuroendocrinol 2003; 15: 1134-1143.

40 Drouin J, Sun YL, Chamberland M, Gauthier Y, De Lean A, Nemer M, Schmidt TJ. Novel glucocorticoid receptor complex with DNA element of the hormone-repressed POMC gene. EMBO J 1993; 12: $145-156$.

41 Reichardt HM, Kaestner KH, Tuckermann J, Kretz O, Wessely O, Bock R, Gass P, Schmid W, Herrlich P, Angel P, Schutz G. DNA binding of the glucocorticoid receptor is not essential for survival. Cell 1998; 93: 531-541.

42 Lookingland KJ, Gunnet JW, Moore KE. Stress-induced secretion of alpha-melanocyte-stimulating hormone is accompanied by a decrease in the activity of tuberohypophysial dopaminergic neurons. Neuroendocrinology 1991; 53: 91-96.

43 Jingami H, Matsukura S, Numa S, Imura H. Effects of adrenalectomy and dexamethasone administration on the level of preprocorticotropin-releasing factor messenger ribonucleic acid (mRNA) in the hypothalamus and adrenocorticotropin/beta-lipotropin precursor mRNA in the pituitary in rats. Endocrinology 1985; 117: $1314-1320$ 
44 Kjaer A, Knigge U, Bach FW, Warberg J. Stress-induced secretion of pro-opiomelanocortin-derived peptides in rats: relative importance of the anterior and intermediate pituitary lobes. Neuroendocrinology 1995; 61: 167-172.

45 Proulx-Ferland L, Labrie F, Dumont D, Cote J, Coy DH, Sveiraf J. Corticotropin-releasing factor stimulates secretion of melanocytestimulating hormone from the rat pituitary. Science 1982; 217: 62-63.

46 Herdegen T, Leah JD. Inducible and constitutive transcription factors in the mammalian nervous system: control of gene expression by
Jun, Fos and Krox, and CREB/ATF proteins. Brain Res Brain Res Rev 1998; 28: 370-490.

47 Kovacs K, Foldes A, Sawchenko P. Glucocorticoid negative feedback selectively targets vasopressin transcription in parvocellular neurosecretory neurons. J Neurosci 2000; 20: 3843-3852.

48 Sebens J, Middelveld R, Koch T, Ter Horst G, Koff J. Clozapineinduced Fos-protein expression in rat forebrain regions. differential effects of adrenalectomy and corticosterone. Eur J Pharmacol 2001; 417: $149-155$. 